\title{
Gross Domestic Product and Foreign Direct Investment: Empirical Evidence from Vietnam
}

\author{
Nguyen Huu Cung, \\ Hanoi University of Industry, Vietnam
}

Doi:10.19044/esj.2019.v15n31p38～URL:http://dx.doi.org/10.19044/esj.2019.v15n31p38

\begin{abstract}
Foreign direct investment contributes to stimulating sustainable economic growth of each country, but economic growth plays an important role in attracting foreign direct investment. The empirical method was employed on a secondary time series data set during the period 2003-2018 to determine the impact of gross domestic product at current prices on foreign direct investment in Vietnam using a linear approach. The empirical results find that the relationship between gross domestic product and foreign direct investment is a positive sign at $1 \%$ significant level. Moreover, the study also shows that business freedom index and investment freedom index has a positive effect on foreign direct investment at 5\% significant level. Based on the findings, the article recommends that Vietnam continues to seek positive solutions to enhance the economic growth rate, continuation in investment and business liberalization.
\end{abstract}

Keywords: GDP, FDI, Foreign investment, Foreign investment attraction, Vietnam

\section{Introduction}

Foreign direct investment (FDI) is an important source of capital for both developed and developing countries. FDI not only adds development investment capital but also is a more stable source of capital than other foreign investment flows. The cause that FDI is based on a long-term view of the market, growth prospects, and does not create the government debt for the host country, therefore it is less likely to change when there are adverse situations. FDI flows have been achieved on a large scale and global scope. According to the study of Nguyen and Liu (2013) suppose that almost all countries and territories around the world have been attracting a certain amount of FDI, only differ in quality and quantity. The positive impact of foreign direct investment is not only on the home country but also on the host country. 
For host countries, there are several important roles in the process of socio-economic development. Firstly, FDI contributes a large amount of capital to the economy. During the period of closed economy, the countries had only one direction to exploit domestic capital for development, may have more foreign aid from a few other countries. While the initial capital accumulation is really limited and not enough to become a driving force for long-term and breakthrough development. Due to these reasons, in fact, most countries have developed a free-market economy, and since then, many socioeconomic sectors have been developed such as international trade, international investment (including FDI), foreign aid, employment, per capita income, living standards, others. In addition, the addition of FDI inflows also helps the host countries reducing the burden of public debt and external debt. Secondly, through FDI, countries receive more modern or different technologies than domestic ones. This is a breakthrough solution for development. In fact, technology is the decisive factor for the growth and development of every country in the world, especially for developing countries. The common prosperity of the human world also comes from the development of technology. Therefore, strengthening technological capacity is always one of the top development priority targets of every country. Thirdly, FDI stimulates the enhancement of corporate and national governance capacity. Through FDI, domestic enterprises will receive effective management methods and skills in production and business, simultaneously promoting a change in awareness and management skills of state officials from the central government to the local government in the trend of international integration. Fourthly, Expanding markets and promoting exports through FDI attraction for the host countries. Export is one of the important determinants of economic growth for each country. In order for export activities to become a reality and to continuously expand both quantity and quality in the context of limited domestic advantages of countries, countries need an external support force including FDI inflows. Especially for developing countries, in fact, although these countries have the ability to produce at a competitive cost but still difficult to penetrate the international market. Most FDI activities are carried out by transnational corporations (TNCs). In all countries, TNCs play an important role in expanding exports due to their position and reputation in the international production and trade system. This analysis shows that the special incentives in developing countries' policies to attract FDI is to encourage export-oriented foreign investment and Vietnam is not an exception. Fifthly, FDI contributes to promoting economic restructuring. Under the impact of the internationalization trend and international division of labor, the intrinsic economy requires a change in line with this trend. Through FDI, countries will have more opportunities to participate in the process of economic integration among countries around the world, thereby, it is 
necessary to change the domestic economic structure to suit the international division of labor and the general level of development, creating favorable conditions in attracting FDI inflows. Sixthly, FDI contributes to developing human resources and job creation. One of the important factors promoting economic growth is human resource development and job creation. Foreign investors are particularly interested in taking advantage of cheap labor in host countries to maximize profits, strengthen their foothold and maintain a competitive advantage in the world market. Therefore, the number of employees are directly worked in FDI enterprises is increasing rapidly in countries, especially in developing countries. Moreover, service provision and outsourcing activities for FDI projects also create more job opportunities. Finally, FDI contributes to the state budget. Through investment activities for production and business sectors in the host country, FDI enterprises contribute to the state budget through taxes such as value-added tax, import, and export tax, special consumption tax, resources tax, individual income tax, others.

How to attract FDI inflows? FDI inflows have been expanded on a large scale and a global scale, causing countries to pay special attention through incentive policies to attract these capital flows, and Vietnam is not an exception. In the history of attracting foreign investment, Vietnam applied Law on foreign investment in 1987. This law could be considered as a first milestone to realize the management mindset shifting from subsidized concentration to freemarket economy, integration with the world, at the same time, it is also the starting time for FDI flows into Vietnam. At the time, Vietnam's foreign investment law was judged by economists to be relatively open and had some of the most progressive contents in the region. However, Vietnam was still a strange region for foreign businesses and investors. Their understanding of the Vietnamese economy was unclear. Moreover, Vietnam's integration with the world economy had many barriers, not yet became a member of many international economic organizations, and not yet had many bilateral and multilateral economic cooperation with other countries, especially to be with developed countries. Growth rate, economic size, and market size were still economic indicators of an underdeveloped country. Per capita income was still a socio-economic indicator of a low-income country. The socio-economic infrastructure had not been invested much by the lack of investment capital. The above-analyzed reasons became the limitations in attracting foreign investment capital, although Vietnam had a number of advantages to attract foreign investors such as the diversity and abundance of natural resources, young and cheap labor force, openness of policies, others. As a result, from 1987 to 1990 , the total registered FDI capital was only about USD 1.1 billion, but the total realized FDI capital was lower and only reached a few hundred million USD (Nguyen and Liu, 2013). 
Since 1991, Vietnam implemented many economic reforms and made a breakthrough for the comprehensive development of the economy, including attracting FDI inflows. As a result, TNCs had gradually been present in Vietnam and there was a rapid increase in both quality and quantity of FDI flows. Based on World Bank data, Vietnam's FDI (net inflows, BoP, current) was USD 0.375 billion in 1991 and increased to USD 2.395 billion in 1996. The Asian financial crisis had happened since 1997 in Thailand and as a consequence that stock markets, large currency centers and prices of other assets in some Asian countries had been effected simultaneously. The economy of several countries was affected serious such as Indonesia, South Korean, and Thailand, and some other countries were slightly impacted such as Hongkong, Malaysia, Laos, Philippines, China, Singapore, Taiwan, Japan, and Vietnam. Several countries had invested directly in Vietnam with a large amount of capital such as Korea, Japan, Taiwan, and others. Therefore, FDI (net inflows, BoP, current) was attracted by Vietnam only about USD 1.59 billion/year in the period 1997-2005. After that, the Asian economy has recovered to the development direction and as a positive phenomenon that many countries continued to increase investment capital into Vietnam, and at the same time, Vietnam also had many reform policies to increase FDI attraction. As a positive result, the average per year during the period 20062018, Vietnam had attracted about USD 9.4 billion (FDI, net inflows, BoP, current). How to attract FDI inflows? What factors affect FDI inflows to Vietnam? Within the scope of this article, the author focuses on analyzing the effect of GDP at current prices on FDI in Vietnam. In addition, the author will also build a second model when adding two other independent variables (investment freedom index, business freedom index) to compare the important role of GDP versus these two variables.

\section{Literature Reviews}

There are many theories related to the appearance and development of FDI flows that were moved from one country to another such as LifeCycle Hypothesis, Market Segmentation Theory, Theory of Competition and Market Performance, Product Cycle Theory, Dispersion Theory of Risk, others. These theories are considered as the light leading investors around the world to discover, plan and implement investment projects in other countries in order to seek maximum benefits, especially economic benefits. FDI inflows have been being implemented in fact not only due to the self-demand of the home countries but also the urgent needs of the host countries in the context of investment capital scarcity, especially with developing countries. To attract FDI inflows, in the first stage, developing countries exploit available advantages such as natural resources, cheap labor, new markets, and potential development, without many competitors, preferential tax policies, others. 
During the period of these available advantages were no longer effective and the quality demand of FDI flows rises up, developing countries like developed countries attract FDI by preferential tax policies for high-tech fields, high quality labor, credit interest rates, development of economic infrastructure, economic liberalization, investment liberalization, business liberalization, high growth rate, economic stability, high per capita income, political stability, others.

In fact, whether in development or developing period, the attraction of FDI flows in countries is based on four main groups of factors such as economic (GDP or GNP, GDP per capita, GDP growth rate, purchasing power of currency, ratio of raw material exports to GDP, manufactured imports/GDP, ratio of exports to imports, others), social (ratio of literacy and school enrolment, availability of technical and professional workers, modernization of outlook, strength of labours movement, extent of urbanization), political (frequency of government change by type and period, number of internal armed attacks period, degree of administrative efficiency, degree on nationalism, colonial affiliation, others), policy (corporate taxation, tax incentive laws, attitude toward joint ventures, local content requirements, limitations on foreign personnel) (Franklin and Ahmed, 1978). Thus, the relationship between these groups of factors and FDI inflows is a positive or negative sign?

There are several types of research on the relationship between taxation and FDI from different perspectives. Peters and Kiabel (2015) studied the influence of tax incentives in the decision of an investor to locate FDI in Nigeria. The results found that the relationship between tax incentives and FDI is a negative effect and significant. This means that tax incentives increase but an increase in FDI is not corresponding. Hsu et al. (2018) had a study with the aim to prove why China stopped tax incentives on FDI since 2008. This article used the provincial-level panel data during the period 19982008 before the reform. The finds show that tax incentives are not a determinant of FDI flows into China in this period but the effect of market size and geographic location on FDI inflows is a positive sign and significant. Another research employed a secondary time series data set for the years 19992011 to analyze the relationship between three independent variables (tax burden for foreign-invested enterprises, unit labor costs, inflation index) and FDI flows in Vietnam (Nguyen and Liu, 2015). The results found that the tax burden for foreign-invested enterprises has a negative effect and significant on FDI flows while the impact of unit labor costs and inflation index on FDI flows is a positive significant at $1 \%$ level of significance. Thus, the relationship between taxation and FDI inflows has a negative sign and significant in all previous studies that this article has reviewed above. 
Ali and Guo (2005) surveyed 22 enterprises operating in China. The purpose of this survey is to find an answer as to why these companies invest directly in China. This means that what factors affect the attraction of FDI flows into China. The results showed that market size is the most important factor for FDI flows, especially for US enterprises. At the same time, the article also found several other main factors affecting the attraction of FDI inflows into China such as local, export-orientated, Asian firms, low labor costs. Ang (2007) employed an annual time series data for the period 1960-2005 to examine and analyze the determinants of FDI in Malaysia. The finds show that the effect of real GDP on FDI is a positive sign and significant while the relationship between GDP growth rate and FDI has a positive sign and negligible significance. Moreover, there are several other factors promoting FDI into Malaysia such as level of financial development, infrastructure development, and trade openness. Finally, higher statutory corporate tax rates and appreciation of the real exchange rate have a negative impact and discouraged FDI inflows into Malaysia. A data set of macro indicators during the period from FY 1973-74 to FY 2007-08 was employed by the study of Mohiuddin and Salam (2011) to analyze factors attracting FDI inflows into Pakistan. The results show that the exchange rate and Real GDP have a positive effect on FDI, this means, an increase in Rupee and real GDP results in a rise in FDI. Moreover, this study also found that a decrease in price level would have a positive impact on FDI flows. Enisan (2017) researched the determinants of FDI in Nigeria. The results found that there are several main factors affecting FDI such as GDP growth, macro instability, financial development, exchange rate, inflation, and discount rate. Demirhan and Masca (2008) estimated a cross-sectional econometric model to determinate factors affecting FDI inflows in developing countries by employing average value of all data for the 2000-2004 period. Mottaleb and Kalirajan (2010) supposed that developing countries have become more favorable destinations than developing countries. This research employed a panel data set from 68 countries including low-income and lower-middle-income developing countries. The results showed, countries where are more successful in attracting FDI under conditions of larger GDP, high GDP growth rate, higher proportion of international trade and more friendly business environment. This means that the relationship between these factors and FDI has a positive effect. Another study used an unbalanced panel data set during the period 1990-2012 to determinate factors affecting FDI flows in developing countries (Kumari and Sharma, 2017). This research found that these are four determinants of FDI flows such as market size, trade openness, interest rate, and human capital. This relationship is a positive sign and significant. Especially, market size is one most significant factors affecting FDI inflows. In Afghanistan, there is a study on determinants of FDI (Wani and Rehman, 2017). This 
research employed a time series data set for the years 2005-2015. The results showed that total debt service, total external debt, GDP and gross fixed capital have a strong positive effect, at the same time, the relationship between inflation and FDI is a negative effect.

\section{Data and Model}

As analyzed above, in economic theory as well as empirical evidence show that FDI is attracted by several different factors in countries. Within the scope of this research, the author performs the regression and correlation analysis by two linear models. A linear regression model is run on the relationship between GDP at current prices and FDI (net inflows). A linear regression model analyzes the impact of GDP at current prices, investment freedom index and business freedom index on FDI (net inflows). Firstly, an empirical analysis method is employed to determine the impact of GDP at current prices on FDI. Secondly, in order to assess the importance level of GDP on FDI, the article adds two independent variables (investment freedom index, business freedom index) into the original model to make a comparison about the role of GDP compared to investment freedom index and business freedom index in attracting FDI into Vietnam. A secondary time series data set for the years 2003-2018 is obtained from the World Bank and The Heritage Foundation. The OLS method is used in both models.

The correlation and regression analysis are conducted 2 steps.

Step 1, the article analyzes the effect of a dependent variable (GDP at current prices) on an independent variable (FDI, net inflows). The regression equation has the following format:

$$
F D I_{t}=\hat{\beta}_{1}+\hat{\beta}_{2} \mathrm{GDP}_{t}+\mu_{t}
$$

Where, FDI is Foreign Direct Investment, net inflows (BoP, current, Bill.US\$)

Where $\beta_{1}$ is Intercept Term and $\beta_{2}$ is Coefficient

GDP $=$ Gross Domestic Product (current, Bill.US\$)

$\varepsilon=$ Error Variable

The regression results of this original model show that the statistical indicators are significant. Because, at a 5\% level of significance, $\rho_{-}$value $=0.000<\alpha=0.05$, large $\mathrm{R}^{2}$ value, block coefficient $\hat{\beta}_{1}$ and $\hat{\beta}_{2}$ be consistent with the economic theory. However, due to the Durbin-Watson test (DW) be too small, this model has autocorrelation phenomena. To remedy this violation, the author uses the general differential equation to perform the regression process. The general differential equation has the following format:

$$
F D I_{t}-\hat{\rho} F D I_{t-1}=\hat{\beta}_{1}(1-\hat{\rho})+\hat{\beta}_{2}\left(\mathrm{GDP}_{t}-\hat{\rho} G D P_{t-1}\right)+\left(\mu_{t}-\hat{\rho} \mu_{t-1}\right)
$$


The autocorrelation test with the extra regression:

The model has no block coefficient: $\quad \varepsilon_{t}=\alpha_{1} \varepsilon_{t-1}+v_{t}$

The model has a block coefficient: $\quad \varepsilon_{t}=\alpha_{0}+\alpha_{1} \varepsilon_{t-1}+v_{t}$

The results of Equation has not block coefficient: $\mathrm{E}(-1)=0.563610, \mathrm{DW}=$ 1.575418

The results of Equation has block coefficient: $\quad \mathrm{E}(-1)=0.564911, \mathrm{DW}=$ 1.582417

Through the DW statistics and the extra regression, the correlation coefficient estimation grade 1 by $\hat{\rho} \cong 0.56$, to substitute into the general differential equation:

$$
F D I_{t}-0.56 \mathrm{FDI}_{t-1}=\hat{\beta}_{1}(1-0.56)+\hat{\beta}_{2}\left(\mathrm{GDP}_{t}-0.56 \mathrm{GDP}_{t-1}\right)+\left(\mu_{t}-0.56 \mu_{t-1}\right)
$$

The regression results show that the general differential equation has statistical significance and be in line with economic theory.

Step 2, the article analyzes the effect of GDP at current prices, investment freedom index and business freedom index on FDI (net inflows). The regression equation has the following format:

$$
F D I_{t}=\hat{\beta}_{1}+\hat{\beta}_{2} \mathrm{GDP}_{t}+\hat{\beta}_{3} I_{N V E S T}+\hat{\beta}_{4} \mathrm{BUSINESS}_{t}+\mu_{t}
$$

Where, FDI is Foreign Direct Investment, net inflows (BoP, current, Bill.US\$)

Where, $\beta_{1}$ is Intercept Term and $\beta_{2}, \beta_{3}, \beta_{4}$ are Coefficients

GDP $=$ Gross Domestic Product (current, Bill.US\$)

INVEST = Investment Freedom Index (score)

BUSINESS $=$ Business Freedom Index (score)

$\varepsilon=$ Error Variable

The statistical indicators show that the model with a dependent variable and three independent variables are statistically significant, consistent with economic theory and the results of previous studies.

4. Results and Discussion

4.1. Correlation Analysis between FDI and GDP at current prices

After performing the operations, the regression results are in the data table below: 
Table 1: Regression Results of the Original Model

\begin{tabular}{crrrr}
\hline \hline Variable & Coefficient & Std. Error & t-Statistic & Prob. \\
\hline C & -0.247184 & 0.908061 & -0.272210 & 0.7894 \\
GDP & 0.061759 & 0.006157 & 10.03107 & 0.0000 \\
\hline \hline R-squared & 0.877860 & F-statistic & & 100.6224 \\
Durbin-Watson stat & 0.858352 & Prob(F-statistic) & 0.000000 \\
\hline \hline
\end{tabular}

Source: Correlation Output of Data Collected

The statistical indicators in Table 1 show that due to $p_{-}$value of GDP at current prices is so small, this means that the relationship between GDP at current prices and FDI (net inflows) is a positive effect and significant. The regression results also show, $\mathrm{R}^{2}=0.877860$, this means that the change of GDP at current prices explained $87.7860 \%$ of FDI's fluctuation. A large value of $\mathrm{R}^{2}$ and F-statistic asserts that the regression model is appropriate. However, the value of Durbin-Watson test is $d=0.858352$ while the sample numbers $n$ $=16$, number of independent variable in the model $\mathrm{k}^{\prime}=1$, inferred $d_{L}=1.106$ and $d_{U}=1.371$, due to $\mathrm{d}<\mathrm{d}_{\mathrm{L}}$, concludes that the model has an autocorrelation phenomena grade 1 . The article fixes this error by using the general differential equation. The regression results are in Table 2 below.

Table 2: Regression Results of the General Differential Equation

\begin{tabular}{lrcrr}
\hline \hline \multicolumn{1}{c}{ Variable } & Coefficient & Std. Error & t-Statistic & Prob. \\
\hline \hline C & 0.055674 & 0.902410 & 0.061694 & 0.9517 \\
GDP-0.56*GDP(-1) & 0.060428 & 0.012110 & 4.989893 & 0.0002 \\
\hline \hline R-squared & 0.656983 & \multicolumn{2}{l}{ Durbin-Watson stat } & 1.578475 \\
Adjusted R-squared & 0.630597 & Prob(F-statistic) & 0.000247 \\
\hline \hline
\end{tabular}

Source: Correlation Output of Data Collected

Based on the regression results show that sign of $\hat{\beta}_{1}$ and $\hat{\beta}_{2}$ is in accordance with economic theory. $\mathrm{R}^{2}=0.656983$, this means that the change of GDP at current prices explained $65.6983 \%$ of FDI's fluctuation. At $5 \%$ level of significance $(\alpha=5 \%=0.05)$, the sample numbers $\mathrm{n}=16$, number of independent variable in the model $\mathrm{k}^{\prime}=1$, inferred $d_{L}=1.106$ and $d_{U}=1.371$. Due to the value $d$ of Durbin-Watson test is $\mathrm{d}=1.567439$ while $\mathrm{d}_{\mathrm{u}}=1.371<$ $\mathrm{d}=1.567439<4-\mathrm{d}_{\mathrm{u}}=2.629$, this demonstrates that the model is not an autocorrelation phenomena. At the same time, due to the $p$ value of GDP at current prices is so small; therefore, the effect of GDP at current prices on FDI is too strong. The regression results also show that the block coefficient estimate of the general differential equation is 0.055674 , therefore, the block coefficient estimate of the original model is $\hat{\beta}_{1}=[0.055674 /(1-0.56)]=$ 0.126532 and the slope estimate of the original model $\hat{\beta}_{2}=0.060428$. The coefficient $\hat{\beta}_{2}$ shows that, in constant of other factors, GDP at current prices 
increases to USD 1 billion, FDI (net inflows) increases to USD 0.060428 billion. Thus, the relationship between GDP at current prices and FDI (net inflows) has a positive effect and significant. This means that GDP at current prices has an important role in attracting FDI net inflows in Vietnam during the period 2003-2018. The result of this study is also consistent with economic theory and a number of previous studies such as Ang (2007), Mohiuddin and Salam (2011), Mottaleb and Kalirajan (2010), Wani and Rehman (2017).

\subsection{Correlation and Regression Analysis between TAX and Independent Variables}

The correlation and regression data in Table 3 shows that GDP at current prices, investment freedom index and business freedom index has a statistically significant effect on FDI net inflows. The impact of these independent variables on FDI net inflows is a positive sign.

Table 3: Regression Results

\begin{tabular}{crrrr}
\hline \hline Variable & Coefficient & Std. Error & t-Statistic & Prob. \\
\hline \hline C & -10.79668 & 3.441511 & -3.137193 & 0.0086 \\
GDP & 0.060750 & 0.007113 & 8.540445 & 0.0000 \\
INVEST & 0.161106 & 0.061044 & 2.639189 & 0.0216 \\
BUSINESS & 0.119893 & 0.052156 & 2.298730 & 0.0403 \\
\hline \hline R-squared & 0.933737 & F-statistic & & 56.36586 \\
Durbin-Watson stat & 2.050504 Prob(F-statistic) & & 0.000000 \\
\hline \hline
\end{tabular}

Source: Correlation Output of Data Collected
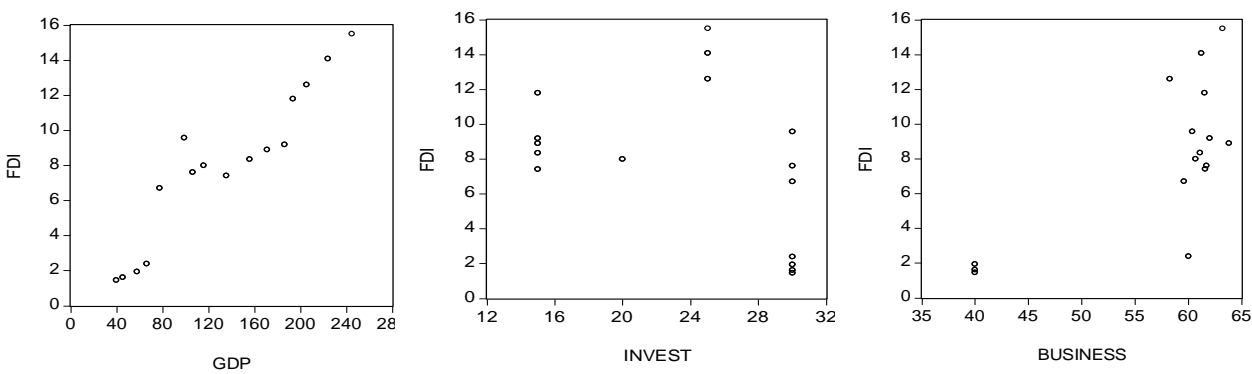

Regression results in Table 3 show that the statistical indicators are significant and the model is consistent with economic theory. Three independent variables have a positive effect on a dependent variable. $\mathrm{R}$-squared $=$ 0.933737, the explanatory level of the determinants of FDI net inflows in terms of $\mathrm{R}^{2}$ by $93.3737 \%$. This means that around 93 percent of the variation in FDI net inflows is explained by this model through independent variables like GDP at current prices, investment freedom index and business freedom index. The value $d$ of Durbin-Watson test by $d=2.050504$ while at $5 \%$ level significance $(\alpha=5 \%=0.05)$, sample numbers $\mathrm{n}=16$, independent variables in the model $\mathrm{k}^{\prime}=3$, inferred $d_{L}=0.857$ and $d_{U}=1.728$. Due to $\mathrm{d}_{\mathrm{u}}=1.728<\mathrm{d}$ 
$=2.050504<4-\mathrm{d}_{\mathrm{u}}=2.272$, this concludes that the model has not and autocorrelation phenomena. With Prob(F-statistic $)=0.000000$, the model is suitable at $1 \%$ level of significance. The author continues to analyze the regression results of each factor to make a comparison of the importance level among the factors.

\section{GDP at current prices}

In economic theory as well as in the research results of previous studies have shown that the relationship between GDP at current prices and FDI inflows is a positive sign. In Table 3, the regression results find that GDP per capita has a positive effect and significant on FDI net inflows at a $1 \%$ level of significance. This value implies that in constant condition of other factors, GDP per capita increases to USD 1 billion, an increase in FDI net inflows is USD 0.060750 billion during the period 2003-3018. Vietnam has always been seeking positive solutions to maintain high economic growth rates among the group of countries with the highest growth rates in the world, such as flexible monetary and fiscal policies, two achieved goals of inflation control and high economic growth, a positive support of government for enterprises to reduce costs and increase profits through tax policies, a reduction in enterprise's costs by a reduction in business and investment procedures, government's credit support with low interest rates and long loan terms in several manufacturing and business sectors (especially for startups), others. Evidence that Vietnam's GDP per capita has increased over the years during the period 2003-2018, for example, the average annual economic growth rate in this period (16 years) is about $6.4 \%$. This research results on the relationship between GDP at current prices and FDI net inflows in Vietnam are also consistent with a number of previous studies such as Ang (2007), Mohiuddin and Salam (2011), Mottaleb and Kalirajan (2010), Wani and Rehman (2017).

\section{Investment Freedom Index}

Overall, investment liberalization is a solution or measures to reduce or eliminate barriers that hinder investment activities from one country to another to create a more competitive and equitable investment environment, and favorable conditions for the movement of investment capital among countries. In economic theory, the relationship between investment freedom index and FDI inflows is a positive sign. This means that, in a constant condition of other factors, an increase in investment freedom index results in an increase in FDI attraction. The correlation results show investment freedom index has a positive effect and significant on FDI net inflows at a $5 \%$ significance level. Based on the slope of $\beta_{3}$, if investment freedom index increases by $1 \%$ then FDI net inflows would increase to USD 0.161106 billion. This also is a true reflection with Vietnam's international commitments on 
investment liberalization in the process of international economic integration. Vietnam's overall goal in implementing international commitments on investment liberalization is to liberalize foreign investment activities by opening business activities and implementing non-discriminatory regime dealing with foreign investors according to a certain schedule. Within the scope of the author's research, this result is a new finding in the case study of Vietnam during the period 2003-2018.

\section{Business Freedom Index}

Business Freedom Index is a set of 10 indicators by using data from the World Bank's Doing Business study: Starting a business-procedures (number), time (days), cost (\% of income per capita), and minimum capital (\% of income per capita); Obtaining a license - procedures (number), time (days), and cost (\% of income per capita); Closing a business - time (years), cost (\% of estate), and recovery rate (cents on the dollar) (According to The GlobalEconomy.com). In theory, as well as practice in countries show that the higher the index is, the stronger its attractiveness to FDI inflows. According to the correlation results from the case of Vietnam shows, business freedom index has a positive effect and significant on FDI net inflows at 5\% significance level. Based on the slope of $\beta_{4}$, if the business freedom index increases by $1 \%$ then FDI net inflows would increase to USD 0.119893 billion. The research results on the relationship between business freedom index and FDI net inflows are consistent with economic theory and also to be a new finding that does not coincide with previous studies on the trend of the impact between these two factors in the case of Vietnam during the period of 20032018.

Within the scope of this research, the results show that GDP at current prices, investment freedom index and business freedom index effect on FDI net inflows into Vietnam. In fact, there are still several other factors that could also impact on FDI net inflows such as per capita income, tax policies, labor costs, distance, political stability, annual inflation index, infrastructure development, others. Therefore, this is the research gap for the next studies of the author.

\section{Conclusion and Policy Implication}

The research results of this article reflect that the effect of GDP at current prices, investment freedom index and business freedom index on FDI net inflows has a positive and significant sign in the Vietnam case for the years 2003-2018. The role of GDP at current prices in attracting FDI net inflows is strongest at a $1 \%$ level of significance while the impact of investment freedom index and business freedom index in attracting FDI net inflows is at 5\% significant level. Thus, in order to compete with regional countries such as 
China, Thailand, Malaysia, Indonesia, and Cambodia in attracting FDI inflows, Vietnam needs to continue flexibly applying fiscal and monetary policies to stimulate economic growth in condition of controlling inflation. GDP growth rate indicates the size of the economy in the future. That is an increase in real GDP, GDP per capita, people's purchasing power. If Vietnam with a high economic growth rate will have many opportunities to attract foreign investors more than other countries in region. Moreover, from the results of this study, Vietnam needs to continue improving investment freedom index and business freedom index. Because these two indexes of Vietnam are lower than in some countries in the region. Average annual in the period of 2003-2018: China (27\% and 51\%), Thailand (41\% and 72\%), Malaysia (43\% and $77 \%$ ), Indonesia (35\% and 52\%), Cambodia (56\% and $41 \%)$, Vietnam (24\% and $57 \%)$.

\section{References:}

1. Nguyen and Liu (2013). Tax Burden and Foreign Direct Investment: Theory and Practice in Vietnam. Advances in Management and Applied Economics, 3(3), 85-103.

2. Franklin and Ahmed (1978). The influence of policy instruments on manufacturing direct foreign investment in developing countries. Journal of International Business Studies, 9(3), 81-94.

3. Peters and Kiabel (2015). Tax Incentives and Foreign Direct Investment in Nigeria. IOSR Journal of Economics and Finance, 6(5), $10-20$.

4. Hsu et al. (2018). Tax Incentives and Foreign Direct Investment in China. Applied Economics Letters, 26(4):1-4.

5. Ali and Guo (2005). Determinants of FDI in China. Journal of Global Business and Technology, 1(2), 21-33.

6. James B. Ang (2005). Determinants of foreign direct investment in Malaysia. Journal of Policy Modeling, 30(2008) 185-189. DOI:10.1016/j.jpolmod.2007.06.014

7. Mohiuddin and Salam (2011). Determinants of Foreign Direct Investment in Pakistan. Journal of Independent Studies and Research_MSSE, 9(1), 117-124.

8. Enisan (2017). Determinants of Foreign Direct Investment in Nigeria: A Markov Regime-Switching Approach. Review of Innovation and Competitiveness, 3(1), 21-48.

9. Demirhan and Masca (2008). Determinants of Foreign Direct Investment Flows to Developing Countries: A Cross-Sectional Analysis. Prague Economic Paper, 2008(4), 356-369. DOI: 10.18267/j.pep.337 
10. Mottaleb and Kalirajan (2010). Determinants of Foreign Direct Investment in Developing Countries: A Comparative Analysis. Margin The Journal of Applied Economic Research, ASARC Working Paper 2010/13, 4(4), 1-28. DOI: 10.1177/097380101000400401

11. Kumari and Sharma (2017). Determinants of Foreign Direct Investment in Developing Countries: A Panel Data Study. International Journal of Emerging Markets, 12(4), 658-682.

12. Wani and Rehman (2017). Determinants of FDI in Afghanistan: An Empirical Analysis. Munich Personal RePEc Archive, MPRA Paper No. 81975. Online at https://mpra.ub.uni-muenchen.de/81975/

13. https://www.heritage.org/index/visualize

14. https://databank.worldbank.org/home.aspx

15. https://www.theglobaleconomy.com/rankings/herit_business_freedo $\mathrm{m} /$ 